\title{
Study on Publication, Trend and Value of Literature on "Network Finance" in the Past Ten Years
}

\author{
Dan Liu \\ Liabrary, Lingnan Normal University, Zhanjiang, Guangdong, 524048, P. R. China \\ South China Sea Silk Road Collaborative Innovation Centre,Lingnan Normal University \\ liudan100liudan@163.com
}

Keywords: Network Finance; Trend; Growth; Value

\begin{abstract}
With the development and popularization of electronic technology, the network is increasingly integrated with traditional finance and has become a new type of finance that is attracting attention in the world today. This phenomenon has aroused widespread concern and research of related industries and scholars. In order to grasp the development of "network finance", this paper uses statistical and comparative analysis methods to analyze the development of "network finance" in the decade of 2003-2013 and its trends in various related research directions, the growth of literature in different years, the theme research core, and explores its value. The study finds that innovation plays an important role in the development of network finance.
\end{abstract}

\section{Introduction}

The formation and development of network finance has profoundly changed people's original ways of economic activities. The network finance has a significant impact on both the micro-economic operation and macro-economic regulation. It is a new way of financial services. This article makes use of China National Knowledge Internet (CNKI) to analyze and discuss the latest financial development status and its research field of "network finance" by using statistics and comparative analysis methods.

\section{Overview of Network Finance}

Overview of Initial Development Phase and Main Mode of Network Finance. "Network finance" is a product of the combination of network technology and financial industry, including the combination of securities, banking, insurance and other industries [1-3]. The first Internet bank in the world, the First U.S. Internet Banking Network, was opened in Atlanta in October 1995, which heralded the development of online banking. That is, from 1995 to 2002, global and US network finance experienced rapid growth, as shown in Table 1 . As can be seen from the table, in 2002, the number of "financial institutions providing online banking services" increased by almost 6,000 times in comparison with that in 1995; that of "financial institutions with web sites" increased by nearly 280 times; as to those with Internet banking the number of households using the Internet was increased by 20 times; the number of households using online banking in the United States was increased by nearly 93 times; the transaction volume of Internet-based bank cards and credit cards (monthly) was increased by 500 times; and the application for loan application via Internet (monthly) has soared from 0 to 1500000 . As a result, we can easily find out that the number of applications for online banking is increasing with the increase in the number of financial institutions that offer online banking services and the number of households using online banking services. The great increase in the number of financial services institutions also reflects the rapid rise of network finance and the extensive use of network finance. Of course, on the other hand, this also reflects the general trend of the development of network finance and the mainstream.

At the same time, the diversification of the development modes of network finance and the main network financial models of countries in different stages of development is also different. The main modes are shown in Figure 1 and Table 2. In Figure 1, the developed countries have more difficulties in terms of functionality and sophistication in network finance, especially in those countries where 
financial networks are concerned, while most developing countries are at moderate levels, providing the primary and advanced network financial products and services and establishing online financial websites. This is also a transitional phase. For most of the backward African countries, it mainly applies comparatively basic financial network modes, such as simple internal network of financial institutions and web application of financial institutions. In combination with Table 2, most of the countries in Africa mainly use the network financial models as the mobile phone model and the post office model, while most developing countries and developed countries apply the smart card model and the financial network model respectively.

Table 1 Increase of network finance from 1995 to 2002

\begin{tabular}{c|c|c|c}
\hline & Region & May 1995 & December 2012 \\
\hline $\begin{array}{c}\text { Financial institutions } \\
\text { providing online } \\
\text { banking services }\end{array}$ & Global & 1 & 6000 \\
\hline $\begin{array}{c}\text { Financial institutions } \\
\text { owning websites }\end{array}$ & Global & 50 & 14000 \\
\hline $\begin{array}{c}\text { The number of } \\
\text { households owning } \\
\text { online banking business }\end{array}$ & Global & 5000000 & 100000000 \\
\hline $\begin{array}{c}\text { The number of } \\
\text { households using online } \\
\text { banking business }\end{array}$ & US & 300000 & 28000000 \\
\hline $\begin{array}{c}\text { Transaction volume of } \\
\text { Internet-based bank } \\
\text { cards and credit cards } \\
\text { (monthly) }\end{array}$ & US & 100000 & 50000000 \\
\hline $\begin{array}{c}\text { Application for loan } \\
\text { application via Internet } \\
\text { (monthly) }\end{array}$ & & & 1500000 \\
\hline
\end{tabular}

Table 2 Network finance modes of different countries

\begin{tabular}{l|l|l|l}
\hline & Most African countries & Developing countries & Developed countries \\
\hline $\begin{array}{l}\text { Main network finance } \\
\text { modes }\end{array}$ & $\begin{array}{l}\text { Mobile telephone mode } \\
\text { and post office mode } \\
\text { etc. }\end{array}$ & Smart card mode & Financial network mode \\
\hline
\end{tabular}

Characteristics and development cause of network finance. The development of network finance in the world is mainly reflected in the development of the banking industry, the development of the securities industry, the development of the insurance industry, and the extensive application of various electronic payment products such as electronic money and credit cards [4-6] This shows the financial universality and the global property; at the same time, what can not be ignored is the low cost of network finance (mainly reflected in the reduction of a variety of intermediary channels), high efficiency (mainly reflected in the characteristics of anytime, anywhere transactions). These are all the reasons that promote the rapid development of internet finance. 


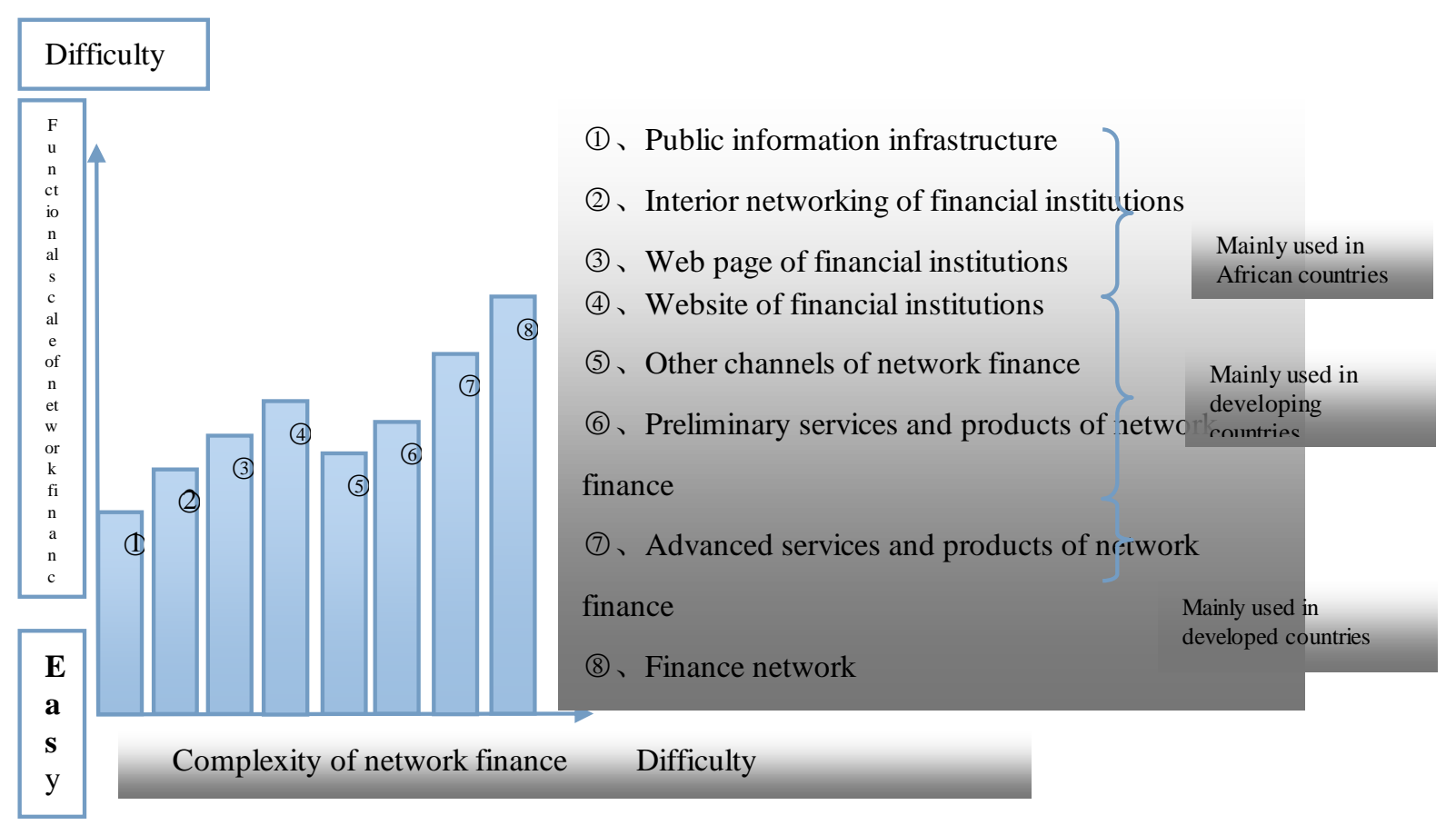

Figure 1. Functions and complexity of network finance

\section{Change Trend of Study on Network Finance}

Because the network finance industry belongs to the emerging industries, together with its wide application and rapid development, it also brings a variety of research topics such as "Network Financial Security", "Network Financial Risk", "Network Financial Regulation", "Network Financial Service" and "Network Financial Product". These topics have received the attention of scholars and research [7-9]. From Table 1, we can see that during the eight years from 1995 to 2002, the development of network finance reached an unprecedented level. In the next three years from 2003 to 2013, eleven years, the total number of articles on the subject of "network finance" was as high as 19,684. As for the trend of network finance research, as shown in Figure 2, from 2003 to 2005, the trend of network finance was gradually increased and then decreased year by year after reaching the highest level in 2005, then was fluctuated again.

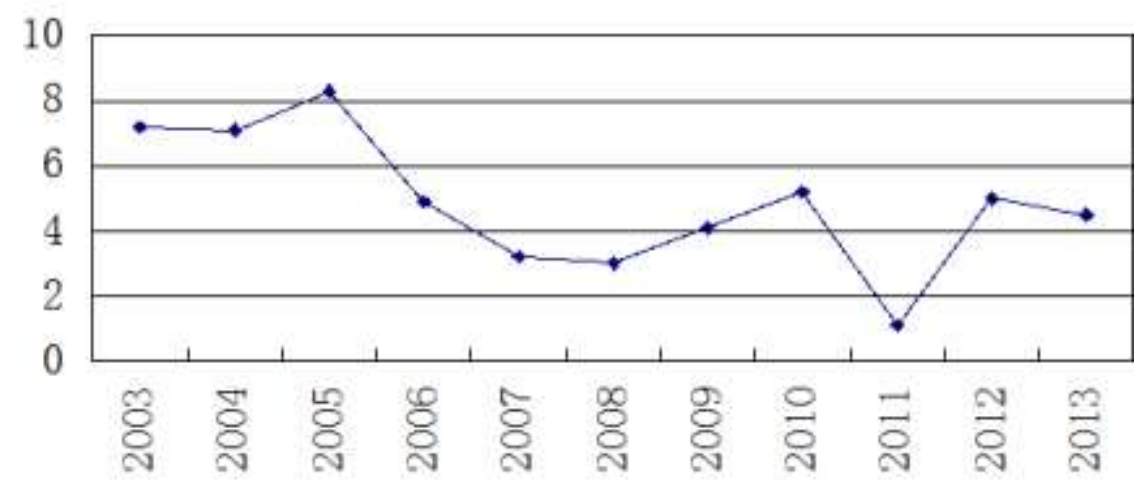

Figure 2. Trend of study on network finance 


\section{Increase of Various Research Topics under Network Finance}

During the 11 years between 2003 and 2013, the literature on "network finance" grew rapidly, as shown in Table 3. Among them, the literature concerning the study of "network financial security" has a cumulative total of 5237 in 11 years, showing an overall increasing trend year by year. Among them, the largest increase in 2013 was 682, accounting for 13\% of the total; "network financial risk" has 21645 literature, and the number of published articles is up to 2013; there are 3118 , accounting for $14 \%$ of the total number of 11 years. There are 31798 literature on" network financial regulation" research, and this shows an increasing trend year by year - up to 4178 or 13\% in the year of 2013. Up to 45850 articles on related research in the field of "network financial services" have been published, up to 8832 in 2013, accounting for about 19\%. "Network financial products" related research has 20298 articles; in 2013 there are 4035 articles taking up $20 \%$. As a result, according to the analysis in Table 3 , it is not difficult to conclude that in the study of "network finance", researchers tend to study the related aspects of "network financial services." In 2013, The literature on "network financial services" is also in the first place, followed by "network financial supervision", and then "network financial risks", "network financial products" and "network financial security." At the same time, it reflects that the literature on "network financial products" has grown at a faster pace than other research literature on "network finance" in the past 11 years because in the year of 2013, although the literature on "network financial products" only had 4035 articles, however, accounted for $20 \%$ of these 11 years, which was significantly higher than the others.

Table 3 Number of literature themed with various research topics of network finance and corresponding proportion from 2003 to 2013

\begin{tabular}{|l|l|l|l|l|}
\hline Research subject & $\begin{array}{l}\text { Number of articles } \\
\text { on the research } \\
\text { topic from 2003 to } \\
2013\end{array}$ & $\begin{array}{l}\text { Number of articles } \\
\text { in } 2013\end{array}$ & $\begin{array}{l}\text { Proportion of the } \\
\text { research topic in } \\
\text { entire research on } \\
\text { "network finance" }\end{array}$ & $\begin{array}{l}\text { Proportion of the } \\
\text { number of articles } \\
\text { in 2013 in the total } \\
\text { number of articles } \\
\text { on this research } \\
\text { topic in the 11 } \\
\text { years }\end{array}$ \\
\hline $\begin{array}{l}\text { Network financial } \\
\text { service }\end{array}$ & 45850 & 8832 & $37.2 \%$ & $19 \%$ \\
\hline $\begin{array}{l}\text { Network financial } \\
\text { regulation }\end{array}$ & 31798 & 4178 & $25.4 \%$ & $13 \%$ \\
\hline $\begin{array}{l}\text { Network financial } \\
\text { risk }\end{array}$ & 21645 & 3118 & $17.2 \%$ & $14 \%$ \\
\hline $\begin{array}{l}\text { Network financial } \\
\text { product }\end{array}$ & 20298 & 4035 & $16.1 \%$ & $20 \%$ \\
\hline $\begin{array}{l}\text { Network financial } \\
\text { security }\end{array}$ & 5237 & 682 & $4.1 \%$ & $13 \%$ \\
\hline
\end{tabular}

\section{Trend of Research Subjects of Related Research Topics of Network Finance}

From Table 3, it can be found that in the 11 years from 2003 to 2013, especially in 2013, the core of the research topic of "network finance" in academia mainly focuses on the research topic of "network finance service". The author believes that this indicates that the network financial services industry has been given more attention and is also growing. Take online banking service as an example. Due to the spread of knowledge and the popularization of technology, the network banking industry has gradually entered the homes of ordinary people. People can enjoy banking services at home, in the office and in various places via network financial services The various services provided do not have to be the same as the traditional way to the real bank, being efficient and convenient, reducing the time, which in one 
aspect also prompted online banking to improve their own quality of service and expand the scope of services in order to maintain fierce competition market share. As the service of "Yu E Bao" project promulgated by Ma Yun brings a huge amount of network revenue to its enterprise groups, it is also urging state-owned banks to follow up and improve the quality of online financial services.

\section{Value Reflected in the Research Literature of Network Finance and Corresponding Discussion}

Value should play a leading role [10]. The development of the Internet, the combination of finance and the Internet have created a new industry in the Internet and brought many issues at the same time. All scholars expressed their opinions and published a large number of relevant documents. From these documents, the value of today's financial development of social networks can be summed up in one work- innovation. Many literatures refer to "business innovation", "management innovation", "service innovation", "regulatory innovation" and "market innovation" in the financial development of social networks. The various research themes under the network finance also embody the concept of innovation, which is also the value that the article draws from these documents. In the aspect of "network financial regulation", we should promote institutional innovation, that is, moderate regulation, but we should not ignore and over-regulate it. In terms of "network financial services" and "network financial products," we should promote industrial innovation based on existing industries, promote the development and maturity of the network finance industry; and in the aspect of "network financial security", promote the innovation of the legal system and solve the "security" issue through appropriate legislation and perfecting existing laws.

\section{Conclusion}

By analyzing the literature published in the 11 years between 2003 and 2013, this paper studies the trend of China's research on network finance in the past 11 years and analyzes the growth and market share of each research topic in the literature periodicals. In the past 11 years, the main body of the research on network finance tends to explore its value and significance for the future development of network finance. Here, I believe that to develop the network finance industry we need continuous innovation and reform. This work is not just a unilateral work carried out by a group of enterprises or the government, but a joint alliance between the government and relevant enterprises. Finally, it will promote the healthy and prosperous development of the network finance industry. Ma Yun said: "The innovation in many industries is triggered by the introduction of outsiders." This also explains to some extent the importance of the government-enterprise cooperation and the cooperation between enterprises and enterprises. Here, it is also not difficult to find that the rapid development of the Internet has not only promoted the transformation, development and prosperity of the traditional financial industry, but also promoted the prosperity and development of the knowledge industry. At the same time, knowledge has also reacted to network finance and promoted the benign development of network finance.

\section{Acknowledgements}

It is a pleasure to acknowledge the support of the project from XU Yan-li being selected in the introduction of shortage top talent of "Sailing up (Yangfan) project" in Guangdong Province in 2014. The project is Leading Industry Development Strategy Research in Emerging Areas in Western Guangdong for Accelerating the Economic Development of Western Guangdong.

It is a pleasure to acknowledge the support from the talents introduction project of universities in Guangdong Province and from Guangdong University of Petrochemical Technology. The project is the Coordinating Development Model Construction and the Path Research of Technical Capability and Technology Management Capability in Equipment Manufacturing Industry.

It is a pleasure to acknowledge the support from the talents introduction project of Guangdong University of Petrochemical Technology. The project is Research on the Coordinating Development Model and Path of Technical Capability and Technology Management in Maoming (513088). 
It is a pleasure to acknowledge the support from comprehensive reform experiment of the Major of International Economics and Trade in Guangdong University of Petrochemical Technology.

It is a pleasure to acknowledge the support from International Education Department in Guangdong University of Petrochemical Technology. The project is Research on Teaching Quality Evaluation for the Major of International Economics and Trade in English in the Background of International Education (2014GDUPTGJ-07).

It is also a pleasure to acknowledge the support from South China Sea Silk Road Collaborative Innovation Center in Lingnan Normal University (2017EL03).

It is also a pleasure to acknowledge the support from Excellent Course "Macroeconomics" in Teaching Quality and Teaching Reform Project in Lingnan Normal University in 2017 (114961700227).

\section{References}

[1] Wang Yuanyue, Ji Jianyue, Yang Enbin. Emerging of Network Finance and Its Development in China. Journal of Harbin Finance University[J]. 2003, 2(4): 42-44

[2] Peng Manwu, Chen Niu. Study on Development of Network Finance. Agricultural Economy and Technology[J]. 2009, 20, (4): 36-53

[3] Li Yuan. Discussion on the Future Development of Financial Networking. Times Finance[J]. 2013, (12): 47

[4] Di Weiping, Liang Hongze. Study on Network Finance. Financial Study[J]. 2000, (11): 27-33

[5] Kong Fanqiang. Current Development Situation and Future Development Trend of Network Finance under New Economic Pattern. China’ s Market[J]. 2010, (22): 64-65

[6] You Xi, Song Wei, Liu Qilin, Yuan Man, Dong Yuxiao. Study on Internet Finance. Times Finance[J]. 2013, (1): 29-35

[7] Li Chunyan, Yu Qiao. Market Expansion of Network Financial Products - Empirical Study on Bank Cards. Financial Study[J]. 2006, (3): 85-93

[8] Liu Guiqing. A Brief Analysis on Risk Prevention of Network Finance in China. Modern Information[J]. 2006,6(6): 53-55

[9] Xiong Jianning. Characteristics of Network Finance and Construction of Security System. Scientific and Technological Information. 2010, (31): 799-800

[10] Bi Hongqiu. Information Freedom: Core Concepts of Library Value. Library Forum. 2005, 25(4):12-14, 87 